Revista Kinesis, Santa Maria v.36, n.3, p. 75-90, set-dez. 2018

Centro de Educação Física e Desportos - UFSM

DOI: $105902 / 2316546431320$

Data de submissão: 27-02-2018

Data de Aceite: 05-12-2018

\title{
FUNK NA ESCOLA: CORPO, CULTURA E MOVIMENTO JUVENIL EM PAUTA
}

FUNK AT SCHOOL: BODY, CULTURE AND YOUNG MOVEMENT ON AGENDA

FUNK EN LA ESCUELA: CUERPO, CULTURA Y MOVIMIENTO JUVENIL EN PAUTA

\author{
Monique Bianchetti \\ mony_bian@hotmail.com \\ Universidade do Vale Do Taquari - UNIVATES \\ Silvane Fensterseifer Isse \\ silvane@univates.br \\ Universidade do Vale Do Taquari - UNIVATES
}

\begin{abstract}
RESUMO
Este texto tem como objetivo discutir a experiência realizada no estágio com o Ensino Médio, em uma escola pública estadual, durante o curso de Educação Física, Licenciatura. A proposta metodológica foi sustentada na perspectiva crítico-emancipatória. Um dos temas da cultura corporal trabalhado foi o funk. Nas quatro aulas ministradas, analisamosimagens, músicasevídeosreferentesaofunk. Aexperiência evidenciouqueodebatesobreofunknaescola érelevantepara os estudantes, pois, aoproblematizaremletras, imagensegestualidades, ampliarama compreensão relativa a aspectos históricos, culturais e sociais que o constituem como manifestação da cultura popular.
\end{abstract}

Palavras-Chave: Educação Física; Ensino Médio; Funk; Cultura Corporal

\section{ABSTRACT}

This text has as aim to argue the pedagogical experience made during the internship with the High School in a public school, during the course of Physiscal Education, Graduation. The methodological proposal was sustained on the perspective critical-emancipatory. In the four classes were used images, musics and videos referents to the content of the funk. The experience evidenced that the debate about funk on school is relevant to the students and that, on problematize letters, images and gestures, it has expanded his understanding on historical appearances, cultural and social that constitute it as demonstration of the popular culture.

Keywords: Physical Education; High School; Funk; Body Culture

\section{RESUMEN}

Este texto tiene como objetivo discutir la experiencia realizada en el estágio con la Enseñanza Media, en una escuela pública provincial, durante el curso de Educación Física, Licenciatura. La propuesta metodológica fue sostenida en la perspectiva crítico-emancipatória. Uno de los temas de la cultura corporal trabajados fue el funk. Realizamos cuatro clases, en que analizamos imágenes, músicas y vídeos referentes al funk. La experiencia evidenciou que el debate sobre el funk en la escuela es relevante para los estudiantes y que, al problematizarem letras, imágenes y gestualidades, ampliaron su comprensión sobre aspectos históricos culturales y sociales que lo constituyen como manifestación de la cultura popular.

Palabras Clave: Educación Física; Enseñanza Media; Funk; Cultura Corporal 


\section{Introdução}

O presente estudo é baseado na prática docente desenvolvida durante o Estágio Supervisionado III - Ensino Médio, em uma escola da rede pública estadual do interior do estado do Rio Grande do Sul, com turmas de $1^{\circ}$ e $3^{\circ}$ anos do Ensino Médio. O estágio, realizado no semestre $A$ de 2017, integra o currículo de formação do curso de Educação Física, Licenciatura da Universidade do Vale do Taquari (UNIVATES). A escola, campo de estágio, atendia aproximadamente 140 alunos, desde $05^{\circ}$ ano de Ensino Fundamental até o $3^{\circ}$ ano do Ensino Médio, dos quais 32 participaram da prática docente desenvolvida na escola.

A partir do estudo do contexto escolar realizado no início do estágio, percebeu-se que os estudantes se posicionavam criticamente em relação aos conteúdos curriculares, o que nos motivou a trabalhar numa abordagem crítico-emancipatória, provocandoos a tomarem iniciativas, assumirem responsabilidades, desenvolverem a autonomia e se posicionarem em relação aos assuntos abordados em sala de aula. Kunz (1994), ao abordar o caráter crítico da Educação Física escolar, destaca a importância de fomentar a capacidade do aluno de analisar e de problematizar as práticas corporais e de tecer as respectivas relações com as diferentes realidades presentes no contexto escolar. Durante o estágio, compartilhamos com os estudantes a escolha e o estudo destes ritmos musicais, bem como, as respectivas danças e o processo de criação de sequências coreográficas.

Trabalhando com a abordagem crítico-emancipatória, o diálogo com os alunos sempre esteve muito presente do início ao fim das aulas. Logo que começamos a definir os conteúdos das danças a serem trabalhadas, os estudantes, imediatamente, propuseram o funk, defendendo sua cultura e o desejo de estudá-la em conjunto. Para eles, o funk é uma dança de grande valor cultural, com estilo próprio. Assim, poderia ser melhor vivenciado na escola se fosse trabalhado através de coreografias, leituras, imagens e músicas.

A escola, no entanto, não apresenta o funk como um de seus conteúdos de ensino. Ao contrário, há restrições quanto à sua inclusão no currículo escolar, em função das letras, melodias, posturas corporais e gestualidades características do estilo. Segundo o diretor da escola, o funk não é dança a ser ensinada, pois, "pelas suas origens e evolução, o funk não diz respeito à cultura local, sendo visto como um apelo explícito à sensualidade, tão explorada pela mídia e pelos meios de massificação. Há outros ritmos e danças mais condizentes com a postura e a filosofia da escola" (ENTREVISTA DIRETOR, 06/06/17).

A professora de Educação Física titular da turma, por sua vez, entendia que o funk faz parte, sim, da cultura dos estudantes da escola, reconhecendo, no entanto, as possíveis tensões ao abordá-lo como conteúdo de ensino:

Vejo o estilo como um ritmo sendo muito aceito entre os jovens, pois a sua batida convida para a dança e é considerada por eles muito boa de dançar. Porém, suas letras e seus 
vídeos, em sua maioria, não são tão interessantes. Pode-se dizer que denigrem a imagem da mulher perante a sociedade, possuem muitos palavrões, fazem apologia ao sexo e ressaltam que o importante é ter dinheiro e tudo o que ele pode proporcionar parece ser mais importante que os valores sociais (ENTREVISTA PROFESSORA, 09/06/2017).

Com base nessas contradições, surgiu o desafio de atender ao desejo dos estudantes, sem, no entanto, desconsiderar as restrições colocadas pela direção ou desrespeitar os princípios que norteiam a proposta educativa da escola. Assim, este estudo teve como objetivo discutir a experiência com o funk realizada com o Ensino Médio, em uma escola pública estadual, durante um estágio do curso de Educação Física, Licenciatura.

\section{Procedimentos Metodológicos}

Foram ministradas quatro aulas sobre o funk. Nas duas primeiras, foram estudados aspectos históricos, especialmente referentes ao Brasil. Foram apresentados e analisados imagens e vídeos de cantores e cantoras, cujo trabalho ganhou evidência em diferentes décadas. Nas duas aulas seguintes, com base nos debates realizados, os alunos escolheram uma música funk e, a partir dela, elencaram um tema-chave para criarem uma paródia. Produziram, então, painéis, apresentando a letra original, a paródia e ilustrações que traduzissem as respectivas mensagens. As falas dos estudantes mencionadas durante essas aulas foram registradas num diário de campo.

Também foram realizadas entrevistas semiestruturadas com questões abertas, com o diretor da escola e com a professora titular de Educação Física. O objetivo das entrevistas era compreender melhor o entendimento dos entrevistados acerca do funk como possibilidade de tema a ser incluído no currículo da escola. As entrevistas foram gravadas, transcritas e devolvidas aos entrevistados para sua aprovação. Foram tomados todos os cuidados éticos no uso dos instrumentos de pesquisa (uso do Termo de Consentimento Livre e Esclarecido - TCLE; uso das informações exclusivamente para fins acadêmicos e científicos; sigilo das identidades dos participantes; atenção a possíveis desconfortos manifestados por eles, entre outros).

Assim, os instrumentos de pesquisa foram a entrevista com o diretor da escola e a professora titular de Educação Física; os registros referentes aos debates com os alunos; a construção dos planos de aula; a escrita de memoriais descritivos.

\section{Dança Funk: Manifestação da cultura corporal juvenil}

O ensino da dança na escola vem sendo defendido em diferentes documentos orientadores da educação brasileira, como os Parâmetros Curriculares Nacionais PCNs (BRASIL, 1998) e a Base Nacional Comum Curricular (BRASIL, 2016), bem como, em documentos do estado do Rio Grande do Sul, como os Referenciais Curriculares 
- Lições do Rio Grande (RIO GRANDE DO SUL, 2009). Esses documentos propõem que conhecimentos acerca da dança sejam ensinados a todos os estudantes brasileiros, uma vez que as diferentes danças integram a cultura corporal de movimento, constituindo-se, assim, num dos conteúdos de ensino da Educação Física escolar.

Segundo Daolio (2004, p. 2), cultura "é o principal conceito para a Educação Física, porque todas as manifestações corporais humanas são geradas na dinâmica cultural, desde os primórdios da evolução até hoje". Em relação à cultura corporal juvenil, Dayrell (2007, p.399) enfatiza "a importância das dimensões simbólicas e expressivas de grupos culturais jovens", que são os autores principais de suas produções, seja de músicas, danças, coreografias ou ilustrações. De acordo com Schwertner e Fischer (2012, p. 399), independente das produções geradas, elas configuram elementos que, de certa forma, "produzem modos de ser jovem, de afirmação de si mesmo na sociedade". Tornar as produções culturais dos jovens estudantes temas constituintes dos currículos escolares nos permite conhecer as múltiplas interpretações e significados atribuídos pelos alunos às suas práticas e experiências. Para Neira e Nunes (2009, p.261),

Tematizar implica procurar o maior compromisso possível do objeto de estudo em uma realidade de fato, social, cultural e política. O que se pretende com a tematização é uma compreensão profunda da realidade em foco e a capacidade crítica dos alunos como sujeitos do conhecimento, desafiados pelo objeto a ser conhecido.

Sendo o funk uma manifestação da cultura juvenil, dar-lhe legitimidade como objeto de estudo é um modo de a escola expressar seu reconhecimento ao jovem como produtor de cultura e de conhecimento. É, também, um modo de acolher a diversidade cultural e de problematizar a cultura da mídia, tendo em vista que é um espaço de produção e de socialização da cultura funk - movimento, estilo e batida /levada musical.

O funk chegou ao Brasil na segunda metade da década de 60, quando Gerson King Combo lançou o álbum Brazilian Soul, com clássicos brasileiros executados com a batida dos EUA. Naquela época, Tim Maia e outros cantores que adotaram "o cabelo black power" começaram a cantar o ritmo e fundaram o "Movimento Black Rio", que se tornou um expoente da cultura afro no país (TAVARES, 2016). O funk carioca, que surgiu na década de 80, teve na cantora Fernanda Abreu um dos seus ícones. Nas "suas canções, ela conceitua o Brasil como nação de múltiplas 'facetas' a partir do Rio de Janeiro, caracterizado como 'Rio 40 graus', como 'capital do sangue quente do Brasil/capital do sangue quente, do melhor e do pior do Brasil" (PAULA, 2007, p. 28).

Fernanda Abreu, que sempre defendeu o funk, numa das suas apresentações em 2013, no "Bloco do Funk", fez a seguinte colocação:

[...] eu gosto de funk, porque eu gosto, antes de mais nada, eu gosto que a gente viva em uma sociedade sem preconceito, e eu acho que o funk é uma expressão musical 
do Rio de Janeiro, assim como qualquer outra, como o samba, como a bossa nova, como o rock, como pop, sertanejo, axé, é tudo Brasil (https://www.youtube.com/ watch?v=CStS9cgYE5s).

Outra figura representativa do funk dos anos 80 foi D J Marlboro. Conforme Machado (2015), as criações de Marlboro "renderam frutos que abriram caminho para a construção de um funk legitimamente carioca" (p.20). Em 1989, junto com outros cantores, Marlboro lançou o disco Funk Brasil, que se tornou um grande sucesso, encarando o processo de nacionalização do funk (ESSINGER, 2005 apud MACHADO, 2015). Para Lopes (2011) apud Machado (2015, p. 20), a produção de Marlboro e de seus parceiros "solidificou o ritmo como um elemento da cultura urbana do país, ganhando visibilidade na mídia nacional”.

O funk, que nasceu em localidades periféricas do Rio de Janeiro, ganha visibilidade à medida que se torna conteúdo de diferentes espaços midiáticos. Para Machado (2015),

[...] o abrasileiramento do funk permitiu que o ritmo ganhasse outros espaços além das periferias. Essa ampliação territorial se deve ao destaque midiático conquistado por algumas músicas, que integram a trilha sonora de uma novela produzida e exibida pela emissora de telecomunicação Rede Globo, no ano de 1991 (MACHADO, 2015, p. 22).

Essa projeção midiática, de acordo com Herschmann (2005) apud Machado (2015, p. 23), "passa a atrair para os bailes os jovens de classe média, oportunidade que lhes oferecia a possibilidade de entrar em contato direto com a identidade e o apelo territorial produzidos por esse estilo musical". Transcorridos quase 70 anos desde as primeiras manifestações nos anos 60, o funk produzido por Tim Maia e Fernanda Abreu foi se modificando. Foram surgindo novos estilos, novas formas de dançar, novos modos de vestir o funk. Essa caminhada histórica do funk foi fundamental para o debate realizado durante as aulas do estágio.

\section{Conhecer a História e Problematizar: Estratégias didáticas para estudar o funk}

Tendo em vista a resistência da escola em relação ao funk, iniciamos o trabalho conhecendo aspectos históricos. Nas duas primeiras aulas, assistimos a vídeos de alguns cantores de diferentes épocas, como Tim Maia, Fernanda de Abreu, Bonde do Tigrão, MC Leozinho, MC Perla, MC Marcinho, MC Anitta, Banda Vingadora, MCs Zaac \& Jerry, MC Kevinho, MC G15, entre outros. O intuito era observar as mudanças que ocorreram com o passar dos anos, nas roupas, nos acessórios, nos movimentos das danças, na forma de colocar-se diante das câmeras e, principalmente, nas letras das músicas.

À medida que os vídeos iam sendo apresentados, a discussão e as críticas dos alunos iam fluindo. Os estudantes assistiam observando e prestando bastante atenção 
à apresentação dos vídeos de Tim Maia e de Fernanda Abreu, sem, no entanto, tecerem comentários, num primeiro momento, possivelmente por ser algo distante deles no tempo, ou por não conhecê-los. Entretanto, quando a batida começou a ficar diferente, apresentando um ritmo mais acelerado e mais conhecido com a apresentação do vídeo "Baile de Favela" (https://www.youtube.com/watch?v=PVthaFMPneY), logo surgiram alguns comentários: “Agora vamos animar! Agora é uma nossa!" (ÉVERTON, 29/05/2017). E a música seguiu tocando, sendo acompanhada por Marcos: "Ela veio quente, e hoje eu tô fervendo; Ela veio quente, e hoje eu tô fervendo, quer desafiar, não tô entendendo [...]" (MARCOS, 29/05/2017). Ao ser apresentado o videoclipe oficial da música, "Metralhadora" (https://www.youtube.com/watch?v=YzCoZGsodoc), Regina comentou: "Meu Deus sora! Meu pai ama essa música!" (REGINA, 29/05/2017), evidenciando que o funk também é apreciado por outros integrantes da família, o que nos permite pensar que a cultura do funk pode extrapolar a geração juvenil.

Ao serem apresentados os vídeos da MC Anitta, imediatamente surgiram comparações com a Fernanda Abreu. Usando um tom de ironia, Regina coloca: "Nossa sora, bem igual, tudo igual!!!!” (REGINA, 29/05/2017). A estudante referia-se a diferenças relativas às roupas, às gestualidades, à postura diante das câmeras e ao apelo erótico. Além dos videoclipes, analisamos imagens de capas de discos das duas cantoras:

Fig. 1 - Imagens das capas de discos das cantoras Fernanda Abreu e MC Anitta

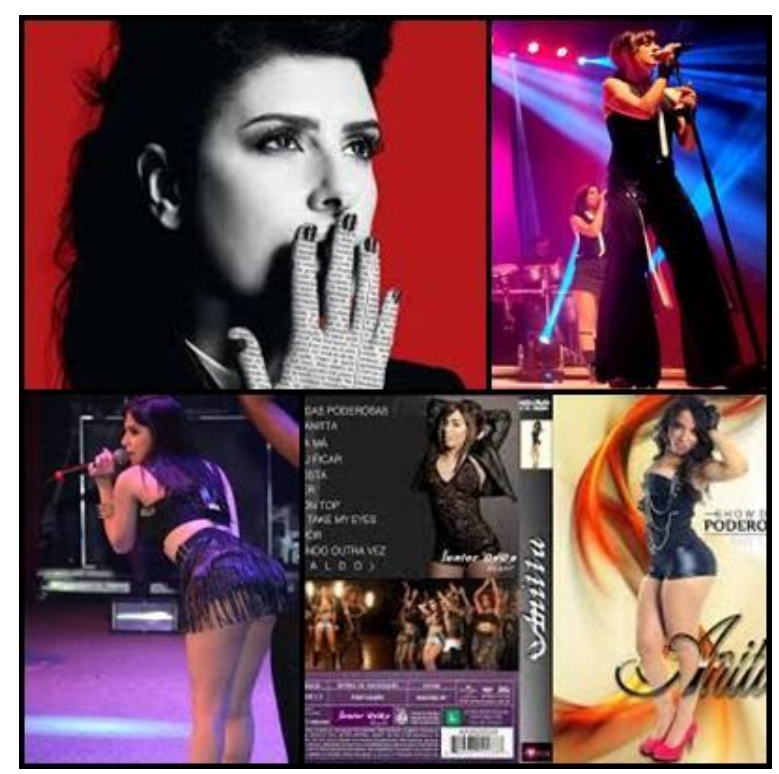

Fonte: https://i.imgur.com/11U1uGH.jpg

E os comentários seguiram:

Regina: “Ela (Fernanda de Abreu) usava roupas!” (REGINA, 29/05/2017).

João: "Ali na Anitta pegou a crise pra ela, não tem pano ali. Pegou a crise, foi feia a 
coisa!” (JOÃO, 29/05/2017).

Mateus: "Anitta só faz com que seus fãs tenham desejo sexual por ela" (MATEUS, 29/05/2017).

Rafael: "Pior que é verdade cara, com as roupas curtas, é só pra criar mais fã-clube e seduzir!" (RAFAEL, 29/05/2017).

Mateus: "Ela só quer chamar atenção!" (MATEUS, 29/05/2017).

O espanto de Regina com a roupa de Fernanda Abreu revela a estranheza e as diferenças no modo de se vestir das duas cantoras, o que leva a uma consequente diferença na exposição dos seus corpos. A grande exposição do corpo em função de roupas de tamanho mínimo constituiu-se num elemento de questionamento da qualidade musical de MC Anitta, o que se visualiza nas falas de Rafael e de Mateus. Parece haver uma crítica no sentido de que a sexualidade da cantora estaria mais disponível a quem aprecia ou consome funk do que a arte ou a própria música dela. Segundo Neckel (2003, p.56),

Os corpos vêm sendo instigados a uma crescente erotização, amplamente veiculada através da TV, do cinema, da música, dos jornais, das revistas, das propagandas, outdoors, e, mais recentemente, da internet, tem sido possível vivenciar novas modalidades de exploração dos corpos e da sexualidade. Tal processo de erotização destes corpos tem produzido efeitos significativos na construção das identidades de gênero e identidades sexuais das crianças, especialmente em relação às meninas, conforme Walkerdine (1999).

A exposição dos corpos, sua exibição diante das câmeras, nas redes sociais ou em imagens de revistas, conforme os estudantes, é algo que pode "vulgarizar" os corpos femininos, colocando-os como objeto de consumo, especialmente em relação ao olhar masculino. Essa exposição demasiada do corpo, sugerem os estudantes, poderia ser uma reprodução do modo como as cantoras se vestem e se comportam na vida pessoal. Há, é possível dizer, uma moralidade que nos remete a questões históricas das relações de gênero: o valor do recato e do controle das sensações e manifestações da sexualidade feminina. Nesse sentido, há, ao mesmo tempo, o gozo da apreciação dos corpos e a crítica aos significados atribuídos a essa exposição.

A experiência de tematizar o funk nas aulas do estágio deixou evidente o quanto ele provoca ideias e sensações contraditórias. Se, por um lado, há quase uma unanimidade de que a levada, a batida e a célula musical do funk são extremamente pulsantes e chamam para dançar, ao mesmo tempo, as coreografias, as gestualidades e as letras das músicas são consideradas “exageradas" poralguns estudantes, emfunção do apelo erótico dosgestose dalinguagem presente nas letras. Há uma clara preocupação com o modo como as mulheres estariam sendo representadas, pois mover-se de uma forma mais livre e expor algumas partes do corpo é considerado, por vários estudantes, como algo bastante questionável.

$\overline{1 \text { Termo utiliza }}$ do pela maioria dos estudantes durantes as discussões realizadas nas aulas. 
As preocupações dos estudantes são também as preocupações da professora de Educação Física titular das turmas participantes do estudo:

Eu acho que a batida dele (funk) é maravilhosa, né? Ela nos convida a nos mexer, a nos movimentar, é só a gente começar a escutar a batida dá vontade de dançar. A música [...] a letra, quando entra na letra, é aí que começa o que é complicado. Praticamente todos os funks que a gente vê agora [...] entram na parte de vulgarização demais da mulher, independente de ser ostentação ou ser o que for o estilo, mas vulgariza a mulher, e aí eu penso assim: que tipo de mulheres nós queremos ser? Uma vagabunda, literalmente, ou a gente quer ser uma mulher com $\mathrm{M}$ maiúsculo, como se diz [...]. Ou a gente quer ser mulher, alguém quer ser respeitada, pelas suas qualidades e não por atributos físicos, porque a Anitta, só pela voz, poderia fazer muito sucesso. Ela não precisa mostrar o corpo, nem nada, porque o que ela tá vendendo é a música dela, e não o corpo dela [...]. Ela está, ela mesma, se diminuindo, ela mesmo se vulgarizando. E porque hoje em dia os homens falam tão mal das mulheres? Porque as mulheres não estão mais se dando ao respeito. Hoje vemos com 10, 12 anos as menininhas querendo namorar. Namorar não no sentido de namoricos e coisa, mas namorar mesmo. Gente, tudo tem o seu tempo, tudo tem a sua fase. [...]. (PROFESSORA DE EDUCAÇÃO FÍSICA TITULAR, 09/06/2017).

Ao discutirmos, nas aulas de Educação Física, o funk com foco nos sentidos atribuídos ao corpo, na gestualidade e na linguagem, ficou evidente a necessidade de também focar as relações de gênero e a sexualidade. $O$ silenciamento em relação a essas questões, que tem sido, historicamente, uma prática de muitas instituições escolares (LOURO, 2016), talvez seja um dos motivos por que o funk, ainda que seja um elemento extremamente significativo da cultura juvenil contemporânea, tem sido excluído dos currículos escolares. Falar de gênero e de sexualidade ainda é uma tarefa que poucos professores tomam para si.

Ao apresentarmos imagens de capas de discos de cantores de funk, questões de gênero surgiram imediatamente:

Fig. 2: Imagens das capas de discos dos cantores MC Sapão e MC Kevinho

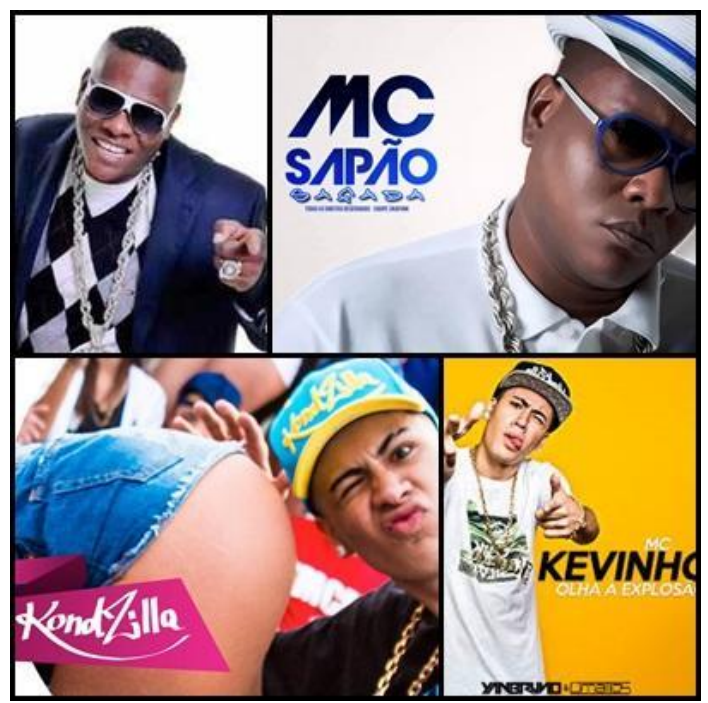

Fonte: https://i.imgur.com/vH1Szst.jpg 
Júnior: “Isso é só malandragem, vida louca!” (JúNIOR, 29/05/2017).

Regina: "Ali literalmente ele colocou a mulher como puta, pra estar quase sem roupa e tacando a bunda na cara dele" (REGINA, 29/05/2017).

O homem do funk, malandro, livre e sedutor diante de um pedaço de corpo de mulher à sua disposição. Questionam os alunos: até onde o corpo da mulher é valorizado e não vulgarizado? Argumentamos, então, que as diferentes culturas femininas e masculinas têm diferentes modos de viver, de agir, de ser, "de vestir-se, de enfeitar-se" e que "a gestualidade, as expressões corporais" dependem muito do tempo em que vivemos, do espaço que habitamos, dos costumes e dos valores que pregamos como sujeitos (ISSE, 2003, p.39).

As representações de feminilidade e de masculinidade presentes nas imagens das capas dos discos acima apresentadas evidenciam o quanto o corpo e seus modos de expressão são usados como linguagem, como elemento de comunicação, como discurso visual na contemporaneidade. Segundo Isse (2003, p.43),

O corpo, [...], além de ser o centro das atenções, tornou-se o discurso visual, não verbal, a respeito do que somos. Ele é, pois, o lugar de construção das identidades. É pelo corpo que nos expressamos e nos aproximamos, e é pelas marcas nele inscritas que nos agrupamos e nos identificamos com os outros.

Cabelos, posturas e expressões corporais, roupas, acessórios e calçados de marca ajudam a compor imagens que traduzem masculinidades associadas à fama, ao luxo, à virilidade e, muitas vezes, a uma certa agressividade. Rafael, João, Mateus e Regina expressam nas falas, sua compreensão acerca de valores transmitidos pelas imagens.

Fig. 3: Imagens do funk ostentação

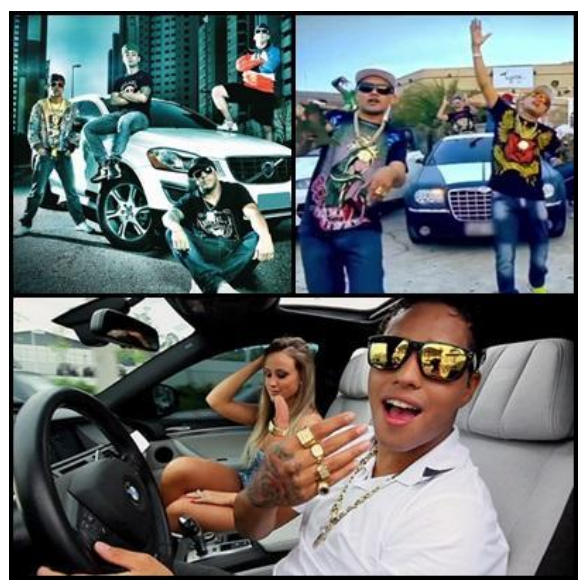

Fonte: https://i.imgur.com/CD1UJJT.jpg 
Rafael: “Funk ostentação, é com luxo, malandragem [...]”(RAFAEL, 29/05/2017). João: "Tem corrente no pescoço e dinheiro"(JOÃO, 29/05/2017).

Mateus: "Roupas de marcas, tênis, bebida e mulher" (MATEUS, 29/05/2017).

Regina: “Mulher interesseira também tem!”(REGINA, 29/05/2017).

Ao analisar o material apresentado durante as aulas, produziram-se reflexões e questionamentos acerca do masculino e do feminino, dos valores sociais, do valor da cultura popular e da cultura juvenil contemporânea e de um estilo de dança que tem todo um apreço pelos jovens e tem sido rechaçado pela educação escolar. A experiência contribuiu para que os estudantes estranhassem aquilo que, numa certa medida, tem sido naturalizado na cultura funk: a exposição e a erotização do corpo feminino, que se coloca diante do deleite do olhar masculino. Ao estranhar essa relação entre homens e mulheres, os estudantes questionaram como as relações de gêneros têm sido construídas e como tem se dado o uso dos corpos masculinos e femininos.

\section{Criação De Paródias: Reinventando a feminilidade no funk}

Como, então, trabalhar os versos, a poética, a linguagem, os sentidos das letras de funk? As paródias apresentaram-se como uma interessante possibilidade de questionamento e de criação. Os alunos foram divididos em grupos e escolheram um dos vídeos a que assistiram, aquele que mais lhes chamou atenção ou a música de que mais gostaram. Deveriam, então, ouvir a música, discuti-la e criar uma paródia dela. As músicas escolhidas pelos dois grupos formados foram: "Deu Onda - MC G15" e "Olha a Explosão MC Kevinho". Acompanhamos as paródias a seguir.

Quadro 1. Paródia da música, "Deu onda"

\begin{tabular}{|c|c|}
\hline Música original: Deu onda & Paródia: Vida que anda \\
\hline Eu preciso te ter & Eu não preciso mais te ter \\
\hline Meu fechamento é você, mozão & Já me cansei de você, mozão \\
\hline Eu não preciso mais beber & Eu tô cansada de sofrer \\
\hline E nem fumar maconha & E de chora na cama \\
\hline Que a sua presença me deu onda & A sua presença me enjoa \\
\hline O seu sorriso me dá onda & A sua risada me enjoa \\
\hline Você sentando, mozão, me deu onda & Você cantando mozão, também me enjoa \\
\hline Que vontade de te ter, garota & Eu não preciso mais te ter, garoto \\
\hline Eu gosto de você, fazer o quê?? & Já não gosto de você, fazer o que? \\
\hline O pai te ama & Vida que anda \\
\hline Que vontade de te ter, garota & Eu não preciso mais te ter, garoto \\
\hline Eu gosto de você, fazer o quê? & Já não gosto de você, fazer o que? \\
\hline O pai te ama,é & Vida que anda, é \\
\hline Opai te ama & Vida que anda \\
\hline Opai te ama, é & Vida que anda, é \\
\hline Opai te ama & Vida que anda \\
\hline
\end{tabular}

Fonte: Das autoras. 
Quadro 2. Paródia da música, "Olha a explosão"



Fonte: Das autoras.

O processo de criação das paródias partiu da análise dos estudantes de algumas palavras e versos que lhes soavam como exageradas, inadequadas ou que se referiam às mulheres como "putas". Muitas foram as risadas enquanto cantarolavam ensaiando alterações da letra original. Mulheres submissas e objeto do desejo masculino passaram a ser mulheres bonitas e que se valorizam. Mulheres explosivas passaram a ser mulheres decididas e respeitadas. O ritmo e a levada que tanto gostam foram mantidos, no entanto, as mensagens passaram a ser bastante diferentes.

Além da criação das paródias, cada grupo teve que ilustrar, através de palavras e/ou desenhos, as respectivas mensagens, o que podemos visualizar nas imagens abaixo: 
Fig. 1 - Ilustração da paródia, "Deu onda"

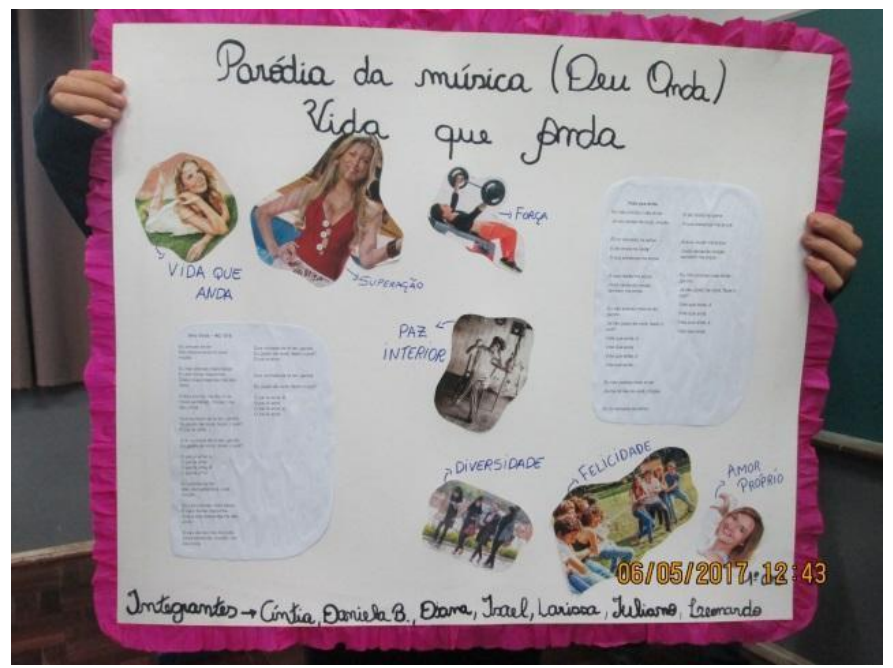

Fonte: Das autoras.

Fig. 2 - Ilustração da paródia, "Olha a explosão"

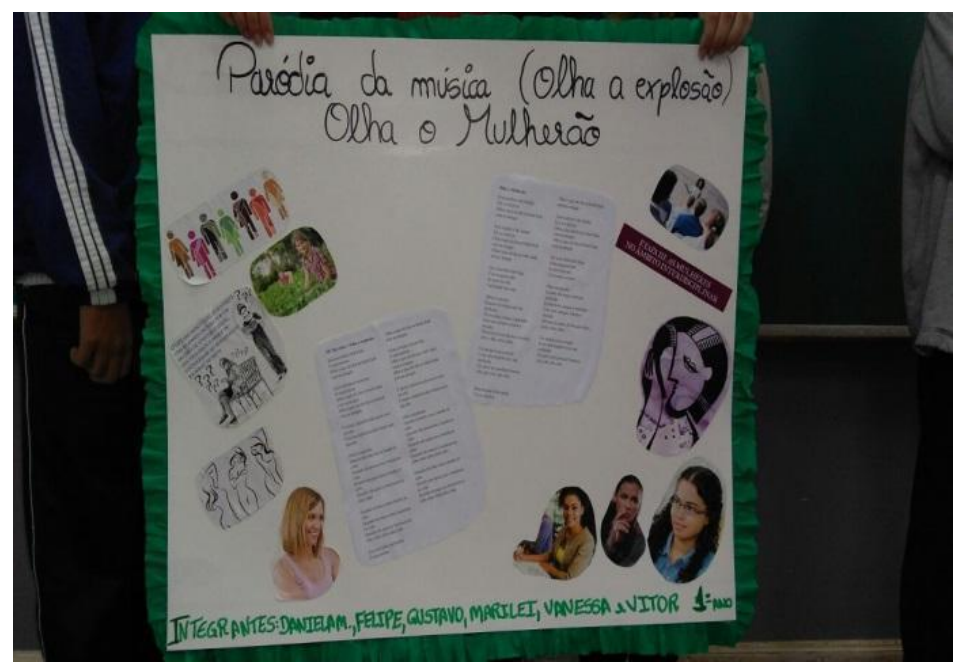

Fonte: Das autoras.

$\mathrm{Na}$ apresentação das paródias e das ilustrações, os grupos cantaram os versos criados, no ritmo da música original. Feito isso, os alunos sugeriram dançar a paródia criada, tendo em vista que as letras não apresentavam, segundo eles, "putaria, erotização ou vulgarização". Se o ritmo, a gestualidade, a levada do funk os convida a dançar, a paródia constituiu-se numa possibilidade de inserção do funk e da cultura juvenil na escola. 


\section{Considerações Finais}

A experiência didática realizada no estágio com o Ensino Médio que tematizou o debate sobre o funk revelou que o tema é extremamente potente para a formação profissional, exigindo sensibilidade, compreensão e conhecimentos relativos a questões internas do meio escolar. Tratar das tensões existentes no contexto escolar foi um importante exercício de escuta, de criação e de intervenção pedagógica, no que diz respeito às proposições curriculares docentes e discentes. A reflexão e o debate a partir de um planejamento pautado na crítica, no diálogo e na autonomia dos estudantes foram elementos fundamentais para a tematização do funk nas turmas de Ensino Médio.

Entendemos que o funk é um conteúdo de muito valor para a educação escolar, ao lado de outros ritmos e gestualidades brasileiras, como o axé, o pagode, o samba, o frevo, o rock, o sertanejo. A história do funk e de seus artistas é também a história da cultura brasileira e, como tal, precisa ser reconhecida e legitimada nos currículos da Educação Básica.

Se o funk carrega em si elementos que colocam em pauta a sexualidade de homens e mulheres, o que gera muitas vezes desconforto e constrangimento em alguns professores e professoras, cabe à escola constituir-se em espaço de formação de seus docentes, isto é, em espaço de debate, de problematização e de construção de relações de gênero que favoreçam o respeito e a liberdade de expressão. É dever da escola falar de corpo, de cultura, de juventude. E, sendo o funk elemento da cultura corporal juvenil contemporânea, é dever da escola lidar com seus desassossegos, temores e limitações e encontrar caminhos para falar e viver o funk em suas múltiplas formas de manifestação.

\section{Referências}

BRASIL. MEC. Parâmetros Curriculares Nacionais para o Ensino Médio: Educação Física. Brasília: SEF, 1998.

BRASIL. MINISTÉRIO DA EDUCAÇÃO. Base Nacional Comum Curricular. $2^{a}$ versão. Brasília: MEC, 2016.

DAOLIO, Jocimar. Educação física e o conceito de cultura. Campinas: Autores Associados, 2004.

DAYRELL, Juarez. T. Juventude, grupos culturais e sociabilidade. Jóvenes - Revista de Estudios sobre Juventud. México. 2007.

ISSE, Silvane Fensterseifer; SANTIN, Silvino - Orientador. Corpo e feminilidade: um estudo 
realizado com meninas adolescentes no contexto da educação física escolar. 2003. 161 p. f. Dissertação (Mestrado em Educação Física) - Escola de Educação Física, Universidade Federal do Rio Grande do Sul, Porto Alegre, 2003.

KUNZ, E. Transformação Didático-Pedagógica do Esporte. ljuí/RS: Editora Unijuí, 1994.

LOURO, Guacira L. Gênero, sexualidade e educação: uma perspectiva pós-estruturalista. 16. ed. Petrópolis: Vozes, 2016.

MACHADO, Fernanda. X. No Balanço do Funk: as tensões que envolvem o ritmo dentro do ambiente escolar. 2015. Dissertação (Mestrado em Educação Física) - Universidade Federal do Espírito Santo, Vitória/ES, 2015.

NEIRA, Marcos. G.; NUNES, Mario. L. F. Educação Física, currículo e cultura. São Paulo: Phorte, 2009.

NECKEL, J. F. Erotização dos corpos infantis. In: LOURO, Guacira L.; NECKEL, Jane F.; GOELLNER, Silvana V. (org.). Corpo, gênero e sexualidade: um debate contemporâneo na educação. 4. ed. Petrópolis: Vozes, 2008, p.53-65.

PAULA, Luciane de. O SLA Funk de Fernanda de Abreu. 2007. Tese (Doutorado em Linguística e Língua Portuguesa) - Faculdade de Ciências e Letras, Universidade Estadual Paulista "Júlio de Mesquita Filho", Araraquara/SP, 2007.

TAVARES, Pedro H. Como surgiu o funk? 2016. Disponível em: <http://mundoestranho. abril.com.br/cultura/como-surgiu-o-funk/> Acesso em: 29 de maio de 2017.

RIO GRANDE DO SUL. SECRETARIA DA EDUCAÇÃO. Referencial Curricular - Lições do Rio Grande: Linguagens, Códigos e suas Tecnologias - Artes e Educação Física. V.2. Porto Alegre: Secretaria da Educação, 2009.

SCHWERTNER, Suzana. F. FISCHER, Rosa. M. B. Juventudes, conectividades múltiplas e novas temporalidades. Educação em Revista, v.28, n.01, p.395-420, mar. 2012.

\section{VÍDEOS}

Tim Maia - Sossego - Disponível em: <https://www.youtube.com/watch?v=qZjEbVMK2Yw> Acesso em: 29/05/2017. 
Fernanda de Abreu - Bloco Funk - Disponível em: <https://www.youtube.com/ watch?v=CStS9cgYE5s> Acesso em: 29/05/2017.

Fernanda Abreu - Rio 40 Graus - Disponível em: < https://www.youtube.com/ watch?v=AhuJ3dUVQvc> Acesso em: 29/05/2017.

Bonde do Tigrão - O baile todo - Disponível em: <https://www.youtube.com/ watch?v=IGhCoW4OWec > Acesso em: 29/05/2017.

MC Marcinho - Glamurosa - Disponível em: <https://www.youtube.com/ watch?v=LBrDIPR5ALg> Acesso em: 29/05/2017.

MC Sapãp - Eu tô tranquilão - Disponível em: <https://www.youtube.com/ watch?v=QQ_1yPvmMRA > Acesso em: 29/05/2017.

MC Perla - Tremendo Vacilão - Disponível em: <https://www.youtube.com/ watch?v=2IMi3GwDgLI> Acesso em: 29/05/2017.

MC Leozinho - Se ela dança eu danço - Disponível em: <https://www.youtube.com/ watch?v=fs5XnExJ6ms> Acesso em: 29/05/2017.

Bola de Fogo - Atoladinha - Disponível em: <https://www.youtube.com/ watch?v=xqtQNZ9Vmqo $>$ Acesso em: 29/05/2017.

Bebês dançam Baile de Favela - Disponível em: <https://www.youtube.com/ watch?v=PVthaFMPneY> Acesso em: 29/05/2017.

MC Anitta - Bang - Disponível em: < https://www.youtube.com/watch?v=UGov-KH7hkM> Acesso em: 29/05/2017.

MCAnitta-SimouNão-Disponívelem:<https://www.youtube.com/watch?v=7Yrghfw1eNo> Acesso em: 29/05/2017.

MC Sapão - Vou desafiar você - Disponível em: <https://www.youtube.com/ watch?v=W6f8jlqRXB4> Acesso em: 29/05/2017.

Banda Vingadora - Metralhadora - Disponível em: <https://www.youtube.com/ watch? $=$ YzCoZGsodoc $>$ Acesso em: 29/05/2017. 
MCs Zaac \& Jerry - Bumbum Granada - Disponível em: <https://www.youtube.com/ watch?v=vWBoLMI_cVw> Acesso em: 29/05/2017.

MCs Zaac \& Jerry - Bumbum Granada na Rua - Disponível em: <https://www.youtube. com/watch?v=4rSFUSnh3uo> Acesso em: 29/05/2017.

MC Kekel - Namorar Pra Quê? - Disponível em: <https://www.youtube.com/ watch?v=byXfKMEmVZc> Acesso em: 29/05/2017.

MC G15 - Deu Onda - Disponível em: < https://www.youtube.com/watch?v=IYxcW8jtFwo> Acesso em: 29/05/2017.

MC Kevinho - Olha a Explosão - Disponível em: <https://www.youtube.com/watch?v=3yd_ eoMOvqk> Acesso em: 29/05/2017.

\section{IMAGENS}

Fig. 1 - Imagens das capas de discos das cantoras Fernanda Abreu e MC Anitta - Disponível em: <https://i.imgur.com/l1U1uGH.jpg > Acesso em: 29 de maio de 2017.

Fig. 2 - Imagens das capas de discos dos cantores MC Sapão e MC Kevinho - Disponível em: <https://i.imgur.com/vH1Szst.jpg > Acesso em: 29 de maio de 2017.

Fig. 3 - Imagens do funk ostentação - Disponível em: <https://i.imgur.com/MfoV6NW.jpg > Acesso em: 29 de maio de 2017.

Fig. 4 - Imagens do funk ostentação - Disponível em: <https://i.imgur.com/umPLhQK.jpg > Acesso em: 29 de maio de 2017. 